\title{
PENGARUH UKURAN PERUSAHAAN, RASIO HUTANG PADA TOTAL ASET, RASIO KELANCARAN KEUANGAN, TINGKAT PULANGAN ASET, DAN PERUBAHAN LABA PER SAHAM TERHADAP WAKTU PELAPORAN AUDIT PADA SELURUH SEKTOR PERTAMBANGAN DI BURSA EFEK INDONESIA PERIODE TAHUN 2012 - 2016
}

\author{
Juan Carlos Pangestu ${ }^{1}$, Jan Hoesada ${ }^{2}$ \\ ${ }^{1}$ Mahasiswa Jurusan S2 Akuntansi, Universitas Tarumanagara \\ Email: juancarlospangestu@gmail.com, id@jcp.web.id \\ ${ }^{2}$ Dosen Pembimbing Tesis, Universitas Tarumanagara
}

\begin{abstract}
The phenomenon of delay in audit reporting occurs on Indonesia Stock Exchange every year. This study aims to empirically examine the effect of firm size, debt to total assets ratio, financial smoothness ratio, asset returns, and changes in earnings per share to audit reporting time. In the Discussion it was found that the debt to total assets ratio (DTA), financial smoothness ratio (CR) and the rate of asset return that has a significant influence on audit reporting time while firm size and changes in earnings per share variables do not have a significant effect on audit reporting time.
\end{abstract}

Keywords: Firm Size, EPS, Audit Time, DTA, CR, ART

\begin{abstract}
ABSTRAK
Fenomena keterlambatan waktu pelaporan audit terjadi di Bursa Efek Indonesia setiap tahun. Penelitian ini bertujuan untuk menguji secara empiris pengaruh ukuran perusahaan, rasio hutang pada total aset, rasio kelancaran keuangan, tingkat pulangan aset dan perubahan laba per saham terhadap waktu pelaporan audit. Dalam Pembahasan ditemukan bahwa rasio hutang pada total aset (DTA), rasio kelancaran keuangan (CR) dan tingkat pulangan aset yang mempunyai pengaruh signifikan terhadap waktu pelaporan audit sedangkan variabel ukuran perusahaan dan perubahan laba per saham tidak mempunyai pengaruh signifikan terhadap waktu pelaporan audit
\end{abstract}

Kata kunci: UkuranPerusahaan, EPS, AuditTime, DTA, CR, ART

\section{PENDAHULUAN}

\section{Latar Belakang}

Laporan keuangan digunakan untuk memberikan informasi tentang kondisi perusahaan yang berguna bagi pihak yang berkepentingan untuk melakukan pengambilan keputusan. Agar bermanfaat untuk pengambilan keputusan, laporan keuangan harus bisa dimengerti, relevan, andal, dan sebanding. Ketepatan waktu laporan keuangan merupakan salah satu faktor penting dalam pelaporan keuangan terutama terkait relevansi (Turel, 2016). Ketepatan waktu pelaporan keuangan perusahaan adalah aspek signifikan dari komunikasi efektif yang terkait dengan fitur pelaporan keuangan lainnya (Gulec, 2017). Pelaporan tepat waktu sangat penting untuk mengurangi dampak kondisi buruk yang terkait dengan hak investor di pasar modal yang sedang berkembang dan menghambat perdagangan orang dalam (insider trading) (Gulec, 2017). Pada tahun 2016, Bursa Efek Indonesia (BEI) melakukan suspensi saham 18 perusahaan dikarenakan belum menyampaikan laporan keuangan audit periode 31 Desember 2015. Pada tahun 2015 
PENGARUH UKURAN PERUSAHAAN, RASIO HUTANG PADA TOTAL ASET, RASIO KELANCARAN KEUANGAN, TINGKAT PULANGAN ASET, DAN PERUBAHAN LABA PER SAHAM TERHADAP WAKTU PELAPORAN AUDIT PADA SELURUH SEKTOR PERTAMBANGAN DI BURSA EFEK INDONESIA PERIODE TAHUN 2012 - 2016

terdapat kepada 63 emiten yang telat menyerahkan laporan keuangan auditannya. Pada tahun 2014 terdapat 54 emiten yang telat menyerahkan laporan keuangan auditannya. Pada tahun 2013 terdapat 49 emiten yang telat menyerahkan laporan keuangan auditannya. Pada Tahun 2012 terdapat 52 emiten yang telat menyerahkan laporan keuangan auditannya. Hal ini menunjukkan fenomena peningkatan pola keterlambatan pelaporan audit emiten

Masalah keterlambatan ini masih terus berlanjut hingga kuartal 1 tahun 2017 dimana 70 perusahaaan belum menyerahkan laporan keuangan interim. Fenomena ini menunjukkan bahwa adanya suatu indikasi dalam laporan keuangan perusahaan yang menyebabkan terjadinya lamanya waktu audit sehingga terjadi keterlambatan pelaporan audit. Dalam kerangka konseptual pelaporan keuangan yang dikeluarkan DSAK IAI (2016), ketepatan waktu merupakan salah satu aspek penting yang mendasari suatu informasi disebut informasi yang berguna. Penelitian terkait waktu pelaporan audit juga memiliki hasil yang berbeda diantanya penelitian Gulec (2017) menemukan ukuran perusahaan, dividen per saham, tipe auditor dan berita baikberpengaruh terhadap waktu pelaporan audit. Penelitian Sufiyati (2017) menemukan hanya ukuran perusahaan dan umur perusahaan yang berpengaruh terhadap waktu pelaporan audit. Penelitian Gahnem dan hegazy (2011) menemukan likuditas, tingkat hutang dan tipe auditor berpengaruh terhadap waktu pelaporan audit.

Sinyal yang buruk dapat menyebabkan terjadinya penurunan harga maupun perubahan keputusan investasi para penanam modal sedangkan sinyal yang baik akan menyebabkan sebaliknya. Hal ini menyebabkan informasi yang buruk akan menyebabkan manajemen untuk menunda pelaporan audit. Pernyataan ini didukung oleh penelitian Gulec (2017); Mouna dan Anis (2013); Ghanem dan Hegazy (2011). Teori kepatuhan juga menjelaskan adanya perspektif atau pandangan atas sikap kepatuhan yang dilakukan perusahaan. Pihak manajemen perusahaan tentu mempunyai perspektif pribadi seperti keinginan mendapatkan bonus yang mendorong terjadinya keterlambatan pelaporan audit apabila kinerja perusahaan dalam keadaan buruk. Penekanan terhadap kepatuhan pelaporan audit telah diatur dalam Kerangka Konseptual Pelaporan Keuangan yang dikeluarkan Dewan Standar Akuntansi Keuangan Ikatan Akuntan Indonesia (2016) maupun Peraturan Otoritas Jasa Keuangan No 29/POJK.04/2016 tentang laporan tahunan emiten atau perusahaan publik. Pemeriksaan terhadap suatu laporan keuangan yang memiliki indikasi buruk yang banyak tentu membutuhkan waktu yang lebih lama dikarenakan auditor wajib melakukan pemeriksaan mendalam. Hal ini tentu dapat menyebabkan keterlambatan waktu pelaporan audit. Pemeriksaan akan semakin lama apabila manajemen berusaha menutupi indikasi buruk laporan keuangan selama proses pemeriksaan.

\section{METODE PENELITIAN}

Penelitian ini menggunakan jenis penelitian kuantitatif yaitu jenis penelitian yang menekankan pada pengujian teori melalui pengukiran variabel - variabel penelitian dengan angka dan memerlukan analisis data dengan prosedur statistik. Data yang digunakan adalah data sekunder yang didapat melalui laporan keuangan perusahaan tahunan yang telah diaudit dan diterbitkan oleh Bursa Efek Indonesia (BEI). Populasi penelitian ini adalah laporan keuangan auditan perusahaan seluruh sektor pertambangan (Sektor pertambangan batu bara, sektor pertambangan minyak \& gas, sektor 
pertambangan logam \& mineral serta sektor pertambangan batu - batuan yang terdaftar di Bursa Efek Indonesia tahun 2012, 2013, 2014, 2015 dan 2016 (5 periode).

Pemilihan sampel dalam penelitian ini menggunakan metode purposive sampling. Purposive sampling merupakan penelitian yang mempunyai tujuan tertentu dalam memilih sampel secara tidak acak berdasarkan kriteria-kriteria tertentu. Kriteria perusahaan yang dijadikan sampel dalam penelitian adalah perusahaaan sektor pertambangan yang terdaftar di Bursa Efek Indonesia tahun 2012 - 2016; Perusahaan yang melaporkan laporan keuangan secara lengkap untuk periode 2012 - 2016. Metode yang digunakan untuk menentukan jumlah sampel dalam penelitian ini adalah menggunakan rumus Slovi. Pada Penelitian ini menggunakan populasi berupa data laporan keuangan audit seluruh perusahaan sektor pertambangan yang berjumlah total 42 perusahaan. Data yang diambil untuk 5 periode tahun dari tahun 2012 - 2016 sehingga memiliki jumlah 210 laporan keuangan perusahaan. Data tersebut diperoleh melalui Bursa Efek Indonesia (ww.idx.co.id). Data yang telah diperoleh terlebih dahulu diolah menggunakan program SPSS versi 24.0 (Stastical Product and Service Solution). Teknik pengolahan data yang digunakan dalam penelitian ini meliputi analisis statistik deskriptif dan pengujian asumsi klasik. Metode pengujian terhadap hipotesis yang diajukan dalam penelitian ini yaitu uji simultan (Uji F), uji parsial (Uji T), serta analisis koefisien determinasi (R2). Tingkat kepercayaan dalam penelitian ini sebesar $95 \%$ dan tingkat kesalahan sebesar $5 \%$.

\section{HASIL DAN PEMBAHASAN}

Penelitian ini menggunakan waktu pelaporan audit (Audit Reporting Time) sebagai variabel dependen (variabel tetap) dan menggunakan Ukuran perusahaan, rasio hutang terhadap total aset, rasio kelancaran keuangan, tingkat pulangan aset dan perubahan laba per saham sebagai variabel independen (bebas). Penelitian ini menggunakan laporan keuangan seluruh perusahaan terbuka sektor pertambangan (sektor pertambangan batu bara, sektor pertambangan minyak \& gas bumi, sektor pertambangan logam \& mineral lainnya, sektor pertambangan batu batuan) di Bursa Efek Indonesia pada tahun 2012, 2013, 2014, 2015 dan 2016. Populasi laporan perusahaan yang digunakan berjumlah 210 laporan keuangan yang berasal dari 42 perusahaan selama 5 periode (2012-2016). Kriteria perusahaan yang dijadikan sampel yaitu

Tabel 1. Kriteria Pengambilan Sampel

\begin{tabular}{|l|c|}
\hline \multicolumn{1}{|c|}{ Keterangan } & Jumlah \\
\hline $\begin{array}{l}\text { Perusahaan Seluruh Sektor Pertambangan ( Sektor batu bara, sektor } \\
\text { minyak \& gas, sektor logam dan mineral, sektor batu batuan) yang } \\
\text { terdaftar di bursa efek indonesia }\end{array}$ & \\
\hline $\begin{array}{l}\text { Perusahaan yang tidak terdaftar di bursa efek indonesia selama periode } \\
2012-2016\end{array}$ & $(6)$ \\
\hline $\begin{array}{l}\text { Perusahaan yang tidak melaporkan keuangan secara lengkap untuk } \\
\text { periode 2012 - 2016 serta tidak memenuhi data yang dibutuhkan dalam } \\
\text { penelitian. }\end{array}$ & \\
\hline Sampel perusahaan yang diteliti & 31 \\
\hline Sampel Laporan keuangan yang diteliti (31 x 5 periode) & 155 \\
\hline
\end{tabular}


PENGARUH UKURAN PERUSAHAAN, RASIO HUTANG PADA TOTAL ASET, RASIO KELANCARAN KEUANGAN, TINGKAT PULANGAN ASET, DAN PERUBAHAN LABA PER SAHAM TERHADAP WAKTU PELAPORAN AUDIT PADA SELURUH SEKTOR PERTAMBANGAN DI BURSA EFEK INDONESIA PERIODE TAHUN 2012 - 2016

Hasil perhitungan rumus slovin untuk populasi berjumlah 210 perusahaan adalah 138 perusahaaan (dibulatkan dari 137,7 ). Hal ini menunjukkan bahwa sampel penelitian ini yang berjumlah 155 telah memenuhi ukuran sampel penelitian yang harus diteliti. Gambaran obyek penelitian dapat dilihat melalui statistik deskriptif yang dibuat berdasarkan sampel penelitian. Tabel menunjukkan nilai minimun, nilai maksimun, nilai rata - rata serta standar deviasi yang dimiliki masing - masing variabel

Tabel 2. Statistik Deskriptif

\begin{tabular}{lr|r|r|r|r} 
& N & \multicolumn{1}{c|}{ Minimum } & Maximum & Mean & $\begin{array}{c}\text { Std. } \\
\text { Deviation }\end{array}$ \\
\hline Audit Reporting Time & 155 & 17 & 274 & 82,30 & 34,082 \\
\hline Ukuran Perusahaan & 155 & 148540000000 & 73543270000000 & $9,46 \mathrm{E}+12$ & $1,530 \mathrm{E}+13$ \\
\hline Debt to Total Asset Ratio & 155 &, 00742 & 1,89768 &, 4685954 &, 29034491 \\
\hline $\begin{array}{l}\text { Rasio Kelancaran Keuangan } \\
\text { / Current Ratio }\end{array}$ & 155 &, 05240 & 78,00439 & 3,1746323 & 7,12093125 \\
\hline Tingkat Pulangan Aset & 155 &,- 72133 &, 92292 &, 0109512 &, 15624759 \\
\hline Perubahan EPS & 155 & $-440,00$ & 347,210 & $-84,7623106$ & 1054,942742 \\
& & & & & \\
\hline
\end{tabular}

Penelitian ini telah memenuhi unsur - unsur pengujian asumsi klasik yaitu uji normalitas, uji multikolinearitas, uji autokorelasi, uji heteroskedasititas. Berdasarkan hasil uji-F , nilai dari $\mathrm{F}$ tabel sebesar 11,339 dan tingkat signifikansi sebesar 0,0000. Dalam menganalisa uji-F dapat melihat nilai $\mathrm{F}$ hitung dan $\mathrm{F}$ tabel ataupun tingkat signifikansi. Nilai $\mathrm{F}$ hitung terdapat di hasil uji $\mathrm{F}$ sedangkan $\mathrm{F}$ tabel menggunakan rumus $(\mathrm{k} ; \mathrm{n}-\mathrm{k})$ dimana $\mathrm{k}$ merupakan jumlah variabel independen dan n merupakan jumlah sampel penelitian. Hasil $\mathrm{F}$ tabel sebesar 2,27 sedangkan $\mathrm{F}$ hitung 11,339. Nilai $\mathrm{F}$ hitung yang lebih besar dibanding $\mathrm{F}$ tabel menunjukkan bahwa secara simultan variabel independen berpengaruh terhadap variabel dependen. Analisa kedua dilakukan dengan melihat tingkat signifikansi uji F . Penelitian ini memiliki tingkat signifikansi sebesar 0,000 dibawah 0,05 maka variabel independen secara simultan berpengaruh terhadap variabel dependen. Nilai Uji tersebut juga menunjukkan bahwa model regresi dalam penelitian ini layak digunakan atau fit serta dapat digunakan untuk memprediksi variabel waktu pelaporan audit (ART).

\section{Tabel Uji F}

\begin{tabular}{llr|r|r|r|r} 
Model & Sum of Squares & df & Mean Square & F & Sig. \\
\hline \multirow{2}{*}{1} &, 842 & 5 &, 168 & $\mathbf{1 1 , 3 3 9}$ & $\mathbf{0 0 0}^{\mathbf{b}}$ \\
\cline { 2 - 7 } & Regression & 2,213 & 149 &, 015 & \\
\cline { 2 - 7 } & Residual & 3,055 & 154 & & \\
\hline
\end{tabular}

Berdasarkan hasil uji koefisien determinasi ganda (R2), nilai koefisien korelasi(R) dalam penelitian ini sebesar 0,525. Nilai koefisien korelasi di atas 0,50 bahwa korelasi atau hubungan yang kuat antara variabel dependen waktu pelaporan audit (ART) dengan variabel independen ukuran perusahaan (UP), rasio hutang pada total aset (DTA), rasio kelancaran keuangan (CR), tingkat pulangan aset (ROA) dan perubahan laba per saham (EPS). Nilai koefisien determinasi ganda adalah 0,276. Hal ini menunjukkan bahwa 27,6 $\%$ variasi atau perubahan waktu pelaporan audit (ART) dapat dijelaskan oleh variasi ukuran perusahaan (UP), rasio hutang pada total aset (DTA), rasio kelancaran keuangan 
(CR), tingkat pulangan aset (ROA) dan perubahan laba per saham (EPS) sedangkan sisanya dipengaruhi oleh variabel lain di luar model regresi ini.

\begin{tabular}{|c|c|c|c|c|c|}
\hline \multicolumn{6}{|c|}{ 4. Tabel uji koefisien Determinasi Ganda } \\
\hline Model & $\mathrm{R}$ & R Square & $\begin{array}{l}\text { Adjusted R } \\
\text { Square }\end{array}$ & $\begin{array}{l}\text { Std. Error of the } \\
\text { Estimate }\end{array}$ & Durbin-Watson \\
\hline$\overline{1}$ &, $525^{\mathrm{a}}$ &, 276 &, 251 & ,12187 & 2,065 \\
\hline
\end{tabular}

Berdasarkan hasil uji-t maka penelitian ini menyimpulkan bahwa variabel Ukuran perusahaan (UP), perubahan laba per saham (EPS) tidak memiliki pengaruh terhadap waktu pelaporan audit (ART) sedangkan variabel rasio hutang pada aset (DTA), rasio kelancaran keuangan (CR) dan tingkat pulangan aset (ROA)memiliki pengaruh terhadap waktu pelaporan audit (ART).

\begin{tabular}{|c|c|c|c|c|c|c|c|c|c|}
\hline \multirow[b]{3}{*}{ Model } & \multicolumn{9}{|c|}{ 5. Tabel Hasil Uji-t } \\
\hline & \multicolumn{2}{|c|}{$\begin{array}{l}\text { Unstandardized } \\
\text { Coefficients }\end{array}$} & \multirow{2}{*}{$\begin{array}{c}\text { Standardized } \\
\text { Coefficients } \\
\text { Beta }\end{array}$} & \multirow[b]{2}{*}{$\mathrm{t}$} & \multirow[b]{2}{*}{ Sig. } & \multicolumn{2}{|c|}{$\begin{array}{c}95,0 \% \\
\text { Confidence } \\
\text { Interval for B }\end{array}$} & \multicolumn{2}{|c|}{$\begin{array}{c}\text { Collinearity } \\
\text { Statistics }\end{array}$} \\
\hline & B & $\begin{array}{l}\text { Std. } \\
\text { Error }\end{array}$ & & & & $\begin{array}{l}\text { Lower } \\
\text { Bound }\end{array}$ & $\begin{array}{l}\text { Upper } \\
\text { Bound }\end{array}$ & Tolerance & VIF \\
\hline 1 (Constant) & 1,610 & ,425 & & 3,791 &, 000 & ,771 & 2,449 & & \\
\hline UP_X1 &,- 021 & ,029 &,- 050 &,- 706 & ,481 &,- 079 & 037 & ,975 & 1,025 \\
\hline DTA_X2 & ,084 & ,046 & , 194 & 1,838 & ,068 &,- 006 &, 174 & ,437 & 2,290 \\
\hline CR_X3 &,- 130 & ,038 &,- 377 & 3,457 & ,001 &,- 205 &,- 056 & ,409 & 2,448 \\
\hline ROA_X4 & 2,194 & ,461 & ,357 & 4,764 & ,000 & 1,284 & 3,104 &, 865 & 1,157 \\
\hline EPS_X5 &,- 085 & 144 &,- 042 &,- 591 &, 555 &,- 370 & ,200 & 971 & 1,030 \\
\hline
\end{tabular}

a. Dependent Variable: ART_Y

\section{KESIMPULAN DAN SARAN}

Ukuran perusahaan tidak mempunyai pengaruh signifikan terhadap waktu pelaporan audit. Ukuran perusahaan yang besar maupun kecil mempunyai kewajiban pelaporan audit yang sama sehingga tidak akan mempengaruhi waktu pelaporan audit. Auditor selalu melakukan fase perencanaan audit sebelum melakukan proses audit sehingga auditor tidak akan mengalami keterlambatan dalam proses audit meskipun perusahaan memiliki ukuran yang besar maupun kecil. Hasil penelitian variabel ukuran perusahaan ini sesuai dengan hasil penelitian Mouna dan Anis (2013), Gahnem dan Hegazy (2011) namun memiliki hasil berbeda dengan Sufiyati (2017), Gulec (2017), Turel (2016) dan Alkhatib dan Marji (2012) .

Rasio hutang pada total aset memiliki mempunyai pengaruh positif signifikan terhadap waktu pelaporan audit. Semakin tinggi nilai DTA menunjukkan perusahaan mengalami risiko yang tinggi. Dalam melakukan prosedur audit, auditor juga seringkali membutuhkan waktu yang lebih dalam melakukan pengujian substantif terhadap hutang. Prosedur audit dalam hutang lebih ditekankan pada asersi kelengkapan dan seringkali auditor membutuhkan waktu lama untuk melakukan konfirmasi atau pembuktian hutang. Rasio DTA yang terlalu tinggi juga dapat menyebabkan perusahaan mengalami sejumlah 
PENGARUH UKURAN PERUSAHAAN, RASIO HUTANG PADA TOTAL ASET, RASIO KELANCARAN KEUANGAN, TINGKAT PULANGAN ASET, DAN PERUBAHAN LABA PER SAHAM TERHADAP WAKTU PELAPORAN AUDIT PADA SELURUH SEKTOR PERTAMBANGAN DI BURSA EFEK INDONESIA PERIODE TAHUN 2012 - 2016

tuntutan hukum seperti dipailitkan oleh kreditur ataupun tuntutan hukum dari investor sehingga manajemen memperulur waktu audit untuk membuat rencana manajemen atas nilai hutang yang terlalu tinggi. Hasil penelitian variabel rasio hutang pada total aset mendukung hasil penelitian Al-Ajmi (2008) namun tidak mendukung hasil penelitian Mouna dan Anis (2013), Ghanem dan Hagezy (2011).

Rasio kelancaran keuangan memiliki pengaruh negatif signifikan terhadap waktu pelaporan audit. Rasio kelancaran keuangan yang tinggi menunjukkan perusahaan dalam kondisi keuangan yang baik dan tidak mengalami kesulitan untuk melunasi pinjaman jangka pendek. Perusahaan akan dengan segera menunjukkan nilai rasio yang tinggi tersebut agar mendapat kepercayaan kreditur ataupun untuk melakukan peminjaman pada kreditur sehingga waktu pelaporan audit semakin cepat atau kecil. Hasil penelitian ini mendukung penelitian Vuran dan Adiloglu (2013), sedangkan tidak mendukung hasil penelitian Sufiyati (2017).

Tingkat pulangan aset berpengaruh positif bukan negatif seperti di hipotesis awal. Secara teori, tingkat pulangan aset merupakan kabar baik karena investor menganggap manajemen memiliki kinerja yang baik sehingga seharusnya investor mengabarkan hal ini. Namun dalam penelitian ini, tingkat pulangan aset memiliki pengaruh positif terhadap waktu pelaporan audit. Tingkat pulangan aset yang rendah akan mempercepat waktu pelaporan audit karena manajemen tidak ingin dicurigai oleh investor melakukan aksi tertentu seperti manipulasi dan sebagainya untuk menutupi kabar buruk tersebut sehingga manajemen lebih baik melaporkan lebih cepat kepada investor sedangkan tingkat pulangan aset yang tinggi akan memperlama waktu pelaporan audit karena manajemen menunda kabar baik untuk menjalankan strategi manajemen seperti pembelian saham kembali. Penelitian ini mendukung sebagian hasil penelitian yang dilakukan Gulec (2017) dan al-jami (2008), dimana penelitian ini memiliki pengaruh positif berbeda dengan penelitian lainnya yang berpengaruh negatif. Penelitian ini tidak mendukung hasil penelitian yang dilakukan sufiyati (2017).

Perubahan laba per saham tidak mempunyai pengaruh signifikan terhadap waktu pelaporan audit. Perubahan laba per saham tidak mempengaruhi manajemen maupun auditor dalam memperpanjang waktu pelaporan audit. Hal ini membuktikan bahwa manajemen tidak ragu dalam memberikan kabar buruk (penurunan laba per saham) kepada investor. Manajemen lebih berfokus pada keefektifan kinerjanya serta keberlangsungan suatu perusahaan dibanding menutupi kabar buruk. Penelitian ini mendukung penelitian Ghanem dan Hegazy (2011) bahwa perubahan laba per saham tidak mempengaruhi waktu pelaporan audit.

Keterbatasan dari penelitian ini diantara lain yaitu penelitian ini menggunakan seluruh perusahaan sektor pertambangan (sektor pertambangan batu bara, sektor pertambangan minyak dan bumi, sektor pertambangan logam dan mineral, sektor pertambangan batu batuan) di Bursa Efek Indonesia (BEI) selama periode 2012 - 2016 (5 periode). Penelitian selanjutnya diharapkan untuk menambah perusahaan dari sektor lainnya di Bursa Efek Indonesia (BEI) ataupun menggunakan seluruh perusahaan yang terdaftar di BEI. Variabel Independen dalam penelitian ini hanya dapat menjelaskan 27,6 persen daripada perubahan di variabel dependen yaitu waktu pelaporan audit. Sebaiknya penelitian selanjutnya mengambil variabel lainnya yang mungkin berpengaruh seperti nilai perusahaan, audit tenure. 


\section{REFERENSI}

Abdollahi, A.F. 2012. Investigation The Effective Factors on Audit Reports Issuance Delay in Iranian Companies That Listed Tehran Stock Exchange Market. .Journal of Basic and Applied Scientific Research 2(8) 8429-8430.

Akerlof, G.A. (1970). The market for "lemons": Quality uncertainty and the market mechanism. The Quarterly Journal of Economics, 84(3), 488-500.

Al-Ajmi, J., 2008. Audit and reporting delays: Evidence from an emerging market. Advances in Accounting, 24(2), pp.217-226.

Alkhatib, K \& Marji, Q. 2012. Audit reports timeliness: Empirical evidence from Jordan. Procedia - Social and Behavioral Sciences 62 ( 2012 ) 1342 - 1349.

Giones, F., \& Miralles, F. 2015. Do Actions Matter More than Resources? A Signalling Theory Perspective on the Technology Entrepreneurship Process. Technology Innovation Management Review, 5(3): 39-45. http://timreview.ca/article/880.

Gulec, O.F. 2017. Timeliness of Corporate reporting in developing economies : evidence from turkey. Accounting and Management Information Systems Vol. 16, No. 3, pp. 219-239.

Ghanem, W.A. and Hegazy, M. 2011. An Empirical Analysis Of Audit Delays And Timeliness Of Corporate Financial Reporting In Kuwait. Eurasian Business Review Volume 1 (2011) 73-90.

Hanafi, M \& Halim, M. 2012. Analisis Laporan Keuangan. Edisi Ketiga. Cetakan Pertama. Penerbit UPP Sekolah Tinggi Ilmu Manajemen YKPN. Yogyakarta.

Ikatan Akuntan Indonesia . (2016). Kerangka Konseptual Pelaporan Keuangan . Jakarta : Dewan Standar Akuntansi Keuangan IAI.

Institut Akuntan Publik Indonesia. (2013). Standar Profesional Akuntan Publik. Jakarta : Salemba Empat

Kasmir. 2010. Analisis Laporan Keuangan.Jakarta: Rajawali Pers

Kieso, D.E., Jerry J. W, and Terry D. W. 2011. Intermediate accounting: IFRS Edition. United States: John Wiley \& Sons, Inc.

Mnif , S.Y \& Tahari, M. 2017. Factors influencing compliance level with AAOIFI financial accounting standards by Islamic banks. Journal of Applied Accounting Research; Leicester Vol. 18, Iss. 1, (2017).

Mouna, A \& Anis, J. 2013. Financial Reporting Delay and Investors Behavior: Evidence from Tunisia. Internasional Journal. Management. Busisness Res., 3 (1), 57-67 Winter 2013.

Pavel, et.al. 2017. Scientific Basis of the Audit Theory. Journal of Advanced Research in Law and Economics; Craiova Vol. 8, Iss. 4(26), (Summer 2017): 1073-1087.

Peraturan Otoritas Jasa Keuangan Nomor 29/ POJK.04/2016 tentang Laporan Tahunan Emiten atau Perusahaan Publik.

Spence, Michael. (1973) “Job Market Signaling”. The Quarterly Journal ofEconomics, 87,( 3) (Aug., 1973), pp. 355-374. The MIT Press.

Sufiyati. 2017. The Impact of Corporate Attributes on the Timeliness of Financial Reporting in Indonesia Stock Exchange. International of Economic Perspectives Volume 11, Issue 1, 1720 - 1730.

Turel, E.T. 2016. An Empirical Analysis Of Audit Delay In Turkey. Annales Universitatis Apulensis : Series Oeconomica; Alba Iulia Vol. 18, Iss. 2, (2016): 97-106. 
Tyler, T. R. (1989). The Psychology of Procedural Justice: A test of the GroupValue Model. Journal of Personality and Social Psychology, 57: pp. 830-

Vuran, B., Adiloğlu, B. 2013. Is Timeliness of Corporate Financial Reporting Related to Accounting Variables? Evidence from Istanbul Stock Exchange. International Journal of Business and Social Science, 4 (6), 58-70.

https://www.cnnindonesia.com/ekonomi/20160630145045-92-142141/telat-sampaikanlapkeu-bei-suspensi-saham-18-perusahaan - diakses 3 Januari 2018. 